\section{Why We Are in Need of Pedagogical Sciences (as Design Sciences) A Few Brief Notes}

\section{Por qué necesitamos de ciencias pedagógicas (como ciencias del diseño) Unas breves notas}

\author{
Por que precisamos de ciências \\ pedagógicas (como ciências \\ do design) breves notas
}

Jan Masschelein*

* Estudios en Ciencias de la Educación y Filosofía, Universidad de Leuven y Johan Wolfgang Goethe Universität de Frankfurt am Main. Director Laboratorio de Educación y Sociedad y Grupo de investigación Educación, Cultura y Sociedad, Universidad de Leuven (Bélgica). Miembro del Alexander Von Humboldt-Stiftung. e-mail: jan.masschelein@ppw.kuleuven.be

\section{Abstract}

The text proposes an approach to the concepts of education, learning and teaching from the design of the school. The analysis is located in the area of "pedagogical sciences", and from the "concept of pedagogy" it provides an approach that goes beyond criticism to learning, developing forms of active resistance and imaginative commitment. There are three central elements in this exercise: first, to understand pedagogy from the figure of the pedagogue; second, to understand the school as a particular type of time and in a particular way to meet the existential, anthropological and social challenge; and third, to understand the pedagogical sciences as (experimental) design sciencies of the school.

\section{Key words}

Pedagogue, pedagogy, design, school, pedagogical sciences, experimental design science

\section{Resumen}

El texto propone una aproximación a los conceptos educación, aprendizaje y enseñanza desde el diseño de la escuela. El análisis se sitúa en campo de las Ciencias pedagógicas y a partir del concepto de 'enseñanza' propone una mirada que va más allá de la crítica al aprendizaje, formulando formas de resistencia activa y compromiso imaginativo. Tres elementos son centrales en este ejercicio: primero, entender la pedagogía desde la figura del pedagogo; segundo, entender la escuela como un tipo particular de tiempo y como una manera particular para hacer frente al desafío existencial, antropológico y social; y tercero, entender las ciencias pedagógicas como ciencia de diseño (experimental) de la escuela.

\section{Palabras clave}

Educación, aprendizaje, escuela, ciencias pedagógicas, pedagogía, ciencia de diseño experimental

\section{Resumo}

0 texto propõe uma abordagem dos conceitos educação, ensino e aprendizagem desde o design da escola. A análise situa-se no campo das Ciências pedagógicas e a partir do conceito de 'ensino' propõe um olhar para além da crítica à aprendizagem formulando formas de resistência ativa e de compromisso imaginativo. Três elementos são fundamentais nesse exercício: em primeiro lugar, compreender a pedagogia desde a figura do pedagogo; em segundo lugar, entender a escola como um tipo específico de tempo e como uma forma particular de enfrentar o desafio existencial, antropológico e social; e em terceiro lugar, entender as ciências pedagógicas como a ciência do design (experimental) da escola.

\section{Palavras chave}

Educação, aprendizagem, escola, ciências pedagógicas, pedagogia, ciência do design experimental.

Fecha de recepción: Octubre 6 de 2015

Fecha de aprobación: Noviembre 16 de 2015 
I $t$ is clear that today both at the level of educational discourses and of actual educational policies it is all about 'learning': 'learning is the nexus' so we can read and since we develop into a 'learningintensive society' we have to look for ways to maximize the learning gains and investigate how we can do that efficiently and effectively (Miller, 2008, p. ii; see also Miller, 2007). It is no surprise, for example, that the OECD is increasingly providing 'frameworks' to influence 'learning' which address 'educational effectiveness' (analysing 'whether specific resource inputs have positive effects on outputs'), 'educational efficiency' (that is, achieving 'better outputs for a given set of resources' or 'comparable outputs using fewer resources') and 'educational sufficiency' (considering 'necessary conditions for providing the affordances most likely to impact on student learning') This can be summarized as follows: 'The idea behind these concepts is that resource inputs [...] are used in educational activities so that they produce desired outputs for the individual, school and community' (Blackmore et al., 2013, p. 4). This idea goes together with the rise of the so-called 'learning sciences.' According to Wikipedia this is

[...] an interdisciplinary field that works to further scientific understanding of learning as well as to engage in the design and implementation of learning innovations, and the improvement of instructional methodologies. Research in the learning science traditionally focuses on cognitivepsychological, social-psychological, and culturalpsychological foundations of human learning, as well as on the design of learning environments. (https://en.wikipedia.org/wiki/Learning_sciences)

This description finds confirmation when the International Society of the Learning Sciences states that it is "dedicated to the interdisciplinary empirical investigation of learning as it exists in real-world settings and to how learning may be facilitated both with and without technology" (https://www.isls.org/).

Meanwhile, there are many voices that critically address this focus on learning. They not only question the implied capitalization, instrumentalization or functionalization of learning, but also the need and importance of the very notion of learning itself for the theory and practice of education (Biesta, 2006; Blacker, 2013; Simons \& Masschelein, 2008a, $2008 \mathrm{~b})$. In this context, we can find the incitement to re-emphasize the importance of the notion of teaching and of education itself, but also calls to revaluate the notion of 'study' (Lewis, 2013). While I am very sympathetic to these critical voices, in this short essay I want to address this issue proposing to approach education, learning, study and teaching from a strictly pedagogical point of view, which-as I will try to show-means from the viewpoint of designing school. I want to insist on the name of 'pedagogical' sciences since I believe that this is a way not just to define a 'domain' or appropriate a discipline, but to resist the present and its learning regime (instead of only criticizing or lamenting it). A way to activate the possible and to call for imaginative engagement instead of submission to the given definition of a state of affairs, even if it is in order to denounce it. It might be seen, in a bit of ambiguous way, as part of what Deleuze and Guattari called a "pedagogy of the concept", since I want to emphasize the concept of 'pedagogy' itself, trying to create another 'taste' of it, to create a (different) habit (Stengers, 2005, p. 162; see also Peters, 2004).

I will do this in three brief steps. First, it is suggested that the notion 'pedagogical' should be understood starting from the figure of the 'pedagogue' and the name of 'pedagogy' and not from 'paideia'. It will then become clear that the pedagogical has essentially to do with 'school' (rather than with teaching), and how it does so. Second, it will be indicated how we should understand 'school' not as an institution but as a particular kind of time-space-matter arrangement and as a particular way to deal with an existential, anthropological and societal challenge. Finally, it is suggested that today this very particular way of dealing with those challenges is in need of defense. Defense does not imply that we have to modernize or revolutionize, but to re-invent, that is to re-design the school. Pedagogical sciences are, therefore, to be conceived as (experimental) design sciences.

\section{Pedagogy and the pedagogue}

In intellectual contexts such as the German, ${ }^{1}$ Polish, Italian or Spanish (including Latin-America), we do find terms like Pädagogik or pedagogía and indeed sometimes ciencias pedagógicas, which refer more generally to the reflections about education in its broadest sense (e.g. including also child-rearing, upbringing). In the anglo-saxon world the name 'pedagogical sciences' is rather rarely used in the field of education and this is true for the academic context (research programs, journals, books, societies, conferences) and the context of education and training programs (e.g. the term does not appear on the websites of major universities presenting their graduate or post-graduate studies). We rather find 'educational

1 Even in the German context, it is rare to find Pädagogische Wissenschaften, but we do find Erziehungswissenschaften and Pädagogik. 
sciences' or 'instructional sciences' besides 'curriculum studies' and increasingly 'learning sciences.' But we do find of course the notion of 'pedagogy'. In this case, we can really assent to the observation of the popular site Wisegeek, where it reads that

[...] [p]edagogical science is the study of methods of teaching and gaining a systematic understanding of how the human mind acquires new information. This includes elements of the teacher, the student, and the overall learning environment that all have an impact on the learning process. So as not to be confused with the study of teaching science subjects itself, pedagogical science is often referred to as just pedagogy or instructional theory. The focus of pedagogical science is on the teaching of children in formal educational settings, but it can also be applied to adults as well as informal methods of learning for all ages. (http://www.wisegeek.com/ what-is-pedagogical-science.htm)

And concerning the notion of 'pedagogy', the Oxford Dictionary of English confirms that pedagogy means: "the method or practice of teaching, especially as an academic subject or theoretical concept". It does most importantly refer to the activities of (school) teachers.

I cannot do justice here to all the differences and nuances in the designation of the field of thought and sciences (in its broadest sense) dealing with education. However, I do not think that it is mistaken to state that in the use of the notion of 'pedagogy' ('pedagogical', 'pedagogics', 'Pädagogik', 'paidagogia', 'pedagogica') there are roughly speaking two fields of reference. The most important one seems to be teaching (and instruction), the second one, more related to the German and Spanish contexts, being a reference to the notion of Bildung or 'cultivation' (going back to the Greek paideia). It makes, of course, little sense to oppose or criticize these uses of the notion 'pedagogy' (etc.). Speech-in-use is not easy to police, but I think that, today, it is important to try to create another taste of this notion, which might happen "only with layer after layer of usage." Therefore,

2 Borrowing a term from Ian Hacking we have also referred to this activity as a 'creative ontology of the educational present' (Simons \& Masschelein, 2007). Hacking adds: "With new names, new objects come into being. Not quickly. Only with usage, only with layer after layer of usage." (Cf. Hacking 2002 , p. 8.) It aims at the invention of new words and concepts, a new language of education that articulates what is at stake today. As such, it is a 'creative act' of forming, inventing and fabricating new concepts as well as introducing new techniques and practices to govern ourselves in the field of education (cf. Deleuze \& Guattari, 1994). Within a broader perspective, these creative acts can be connected to an 'ethics of de-governmentalization' and can contribute, more precisely,
I want to trace back the terms pedagogical and pedagogy to the emergence of the Greek paidagogos (and paidagogia ${ }^{3}$ ) which I think allows activating another imaginative dealing with the field of education.

One of the oldest images we have from the paidagogos clearly shows that this figure was not at all to be identified straightforwardly with the teacher (see figure 1). On this image, we can see how teachers are engaged with pupils while the pedagogue - typically shown with a staff- is sitting in front of one of the pupils.

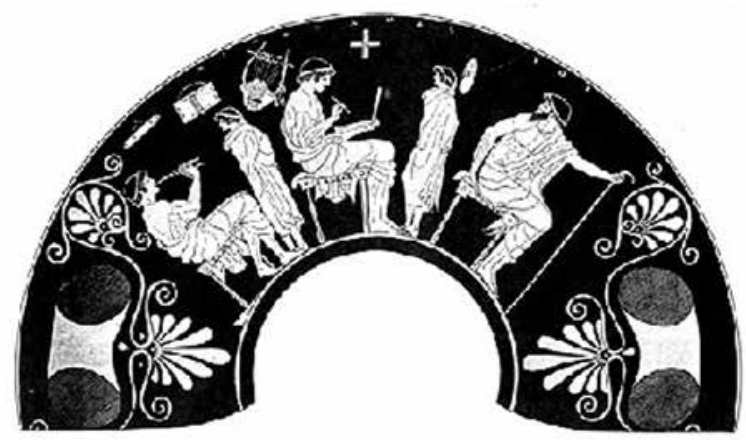

Figure 1 School scene. 480 BCE.

Antikensammlung, Staatliche Museen, Berlin, Germany. Source: Art Resource.

This distinction between teacher and pedagogue has been repeatedly observed and emphasized (e.g. Castle, 1961; Roberts \& Steiner, 2010; to name just a few). However, it seems to always fall immediately back into oblivion-which is reflected in the identification of pedagogy with (the art of) teaching. Let me try once more to revive the distinction but by proposing to emphasize two particular elements regarding this distinction: the relation to the public (to certain extent in line with Roberts \& Steiner 2010, and with Serres 1999) and, especially, to the school (in line with Masschelein \& Simons, 2014). To put it quite bluntly and not nuanced: teachers (can) exist without the public and the school; pedagogues are crucially related to them. The term paidagogos

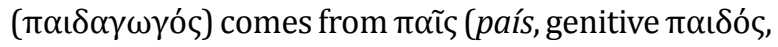
paidos) which means "child" and ő $\gamma \omega$ (ágō) which means "lead" or "to get going" or "set into motion". So, literally, "to lead and accompany the child". This is in

to a 'governmentality of ethical distance' (cf. Gros, 2004, pp. 520-523)

3 Paidagogia (paidagogeia) was the name for the space where the pedagogues sometimes remained during the time of teaching-so, it was not the room (space) of teachers (didaskaleia). (See Harten 1999, p. 20.) 
the first place to be understood in terms of displacement, i.e. to accompany on the way and one of the most important 'ways' was the one leaving the house (oikos) to the sites of exercise and study (the school, the palastrum) (Harten 1999, pp. 8-27). The spacetime in which the pedagogue moves and is to be found is therefore mainly the space-time in-between house and school, on the thresholds of the school, and in the coulisses and the back of classrooms. The pedagogue is leading out, which is at once softening-so to say-the exposure of the child (while becoming exposed himself), but also supporting and sustaining the child (at once anxious and curious) to enter the school. The pedagogue stays at school to watch over the fact that it remains a school (and that teacher's 'love' for the child remains the right love so, and the child remains a pupil ${ }^{4}$ ). According to Roberts and Steiner "... the paidagogos derived his liminality from his position as both enabler and disabler of democratic authority and as the servant-leader who occupied the pedagogical space between the private world of the household and the institutional world of schooling" (2010). In my understanding, he or she is precisely also preventing 'school' from becoming (just) an institution, and is therefore protecting both the school-so that it remains being a school, i.e. a pedagogic form and no political (state) device-and the child-so that he or she remains a 'pupil', and becomes no 'learner' of something predefined, or a 'disciple' of a doctrine or teaching.

From here, we could suggest that the pedagogue is concerned not in the first place with 'learning' as such, but with school-learning or learning in the milieu of the school, and that this concern always includes the leaving of the oikos and, thus, is related to the public. The pedagogue is therefore crucially related to a voyage outside. And this voyage is leaving the place of birth (in Latin, nasci means 'to be born' and it is related to the notion of 'nature'),

[...] the womb of [the] mother, the shadow cast by [the] father's house and the landscape of [once] childhood. [...] The voyage of children, that is the naked meaning of the Greek word pedagogy. [...] [being] seduced to become engaged in it. To seduce: to lead elsewhere. To split off from the so-called

4 It might be suggestive to recall that in the Alcibiades, Socrates clarifies to Alcibiades that the right 'pedagogic' love towards him is not the one that is the love for his beauty or his body or his richness, but for his 'self' i.e. for his soul. And equally suggestive that the pedagogue (not for Socrates and not for the pedagogue he is referring to) is the one who is more important for the care of the self, to use Foucault's translation of epimeleia heautou, than the teacher, since he has a different closer contact to the pupil (e.g. Castle 1961, pp. 63-64). natural direction. [...] To split off necessarily means to begin on a road that cuts across and leads to a unknown place [...]. (Serres 1997, p. 8)

It is a second birth. And Michel Serres continues

[...] [during] this voyage with the other toward alterity [...] lots of things change. You must love the language that transforms the slave into the master himself; and thus the trip into school itself; and that transforms this emigration into instruction. The slave knows the outside, the exterior, exclusion, what it is to emigrate; stronger and adult, he catches up a bit with the more fortunate child, establishing a temporary equality that renders communication possible. [...] There is no teaching without this self-begetting. Thus, from above, the rich child speaks to the poor adult slave who answers, from his greater stature; maybe, all of a sudden, they will take each other's hand, in the wind and beneath the rain, forced to shelter a moment beneath the foliage of the beech tree, above which the third person thunders: it is snowing, it is cold. Other and experiencing alterity painfully, the slave is familiar with the exterior, has lived outside. Thus the world enters the body and the soul of the greenhorn: impersonal time and also the strangeness of the excluded, iste, the derided slave, and soon that of the master, ille, still far away, at the end of the voyage. Before arriving, he is no longer the same, reborn. The first person becomes the third person before entering the school door. [...] All pedagogy takes up the begetting and birthing of a child anew. (Serres, 1997, pp. 48-49. My italics)

There are many things to be taken from this wonderful description, but let me just point here to one particular element: the wandering (with the pedagogue!) that establishes a temporary equality, implies a split off from the so-called natural direction, leading to a unknown place but also to becoming a third person at the threshold of the school, the third person referring to (the pronoun of) a person which is undefined (or unknown). In line with what I have been suggesting elsewhere together with my colleague Maarten Simons (Masschelein \& Simons, 2013), we could think of the school when it actually operates as school (not as institution, but as particular time-space-matter arrangement) to be the materialization of this unknown or third place-as Serres also calls it-, where one enters as undefined person, without natural destination. Thereby not forgetting that the school can be approached as this 'third place' where the world is 'unknown', that is in a particular 'state', equally undefined. To which we can add that once at school one becomes a 'pupil' like anyone else and that one of the main meanings of the 
Latin pupillus, from which derives the English pupil, is 'orphan' and 'foundling'. Making that at school one is not only without natural destination, but also without 'natural family' (be it the common family or the 'national' family or whatever family) and therefore can find one's own destination and become part of any family-to-come. Implying that the community of the school, as far as it is and remains school (which is often also not the case), is not based on a past or a future, not based on an identity which they would share. Its members constitute a collective which is radically 'contemporary' - there is only a common language, common history, common education to come. The eyes and the hands of the pupils are too much occupied with what is on the blackboard or on the table to be allowed a clear conscience of the community (or identity) they would constitute (see also Groys, 2015, p. 69).

From this understanding, one could state that relating the notion of pedagogy to teaching and also too easily to paideia (as we can find it for instance in some German tradition of thinking about Bildung, e.g. Adler, 1982; Jaeger, 1947) misses this very crucial reference to the pedagogue and therefore also the essential reference to the particularity of the school. Let me now try to clarify a bit more this particularity of the school relying on the way Maarten Simons and myself have proposed to understand the operations of the school in our defense of it (Masschelein \& Simons, 2013).

\section{The school: Taking care and paying attention}

To clarify how to understand the notion school, let me try to approach the issue of education from another angle by indicating to what kind of issue education does try to respond or constitutes the response (Ricken, 1999, pp.319-320). This was also the way in which Sigfried Bernfeld approached the issue stating that education is the whole of reactions of a society to the fact of development ("die Summe der Reaktionen einer Gesellschaft auf die Entwicklungstatsache", Bernfeldt, 1925/1973, p. 51). From this, I take the very important observation that education is a matter of society (not of individuals). However, I think that Bernfeld's formulation overlooks the particularity of the response that has emerged with the appearance of the school. This response, I suggest, implies to conceive of the question to which education is the answer not only in terms of development, implying that society is confronted with the arrival of beings which are in becoming and have to be sustained in their development and grow, but to conceive of it also in terms of (the fact of) natality. As Hannah Arendt phrases it, implying that society is confronted and challenged by beings that are also new beginnings which at once threaten (the given) society and allow for its renewal. To put it differently, we could state that every society has to deal with the existential and anthropological conditions to be confronted with the arrival of 'new ones' or new generations (which we should not simply understand in terms of actual age). Many societies respond to this confrontation through practices of initiation and socialization, but some others also respond by education i.e. by taking these 'new ones' to school. That, one could say, constitutes the pedagogical response. The particularity of this response is that it relies (1) on the unique and radical creed or credo that human beings are all equal, that they have no natural destination and that everybody can learn everything (i.e. what you can learn is not 'naturally' predefined or fixed and what you have to learn is not predefined), and (2) on the decision of a society to give itself (i.e. the fundamental grammars of its practices) out of hands or put them on the table. Borrowing Stengers words when referring herself to Whitehead we should see it as "[...] a decision without decision-maker which is making the maker" (Stengers, 2005b, p. 185). It is this pedagogical credo and societal decision that are materialized in the design of schools as particular ways to deal with the new generations and to take care of the world that is disclosed for them. The school, thus, emerged as a decision providing schole or free time, that is, non-productive time, to those who by their birth and their place in society (their 'position') had no rightful claim to it. ${ }^{5}$ That is also the reason why Bernard Stiegler defines the school as 'otium/scholé for the people' (Stiegler $2006 / 2008$, p. 150). School is indeed literally a place of schole, that is the spatialisation and materialisation of "free time" and, thus, of the separation of two uses of time. What the school did was to establish a time and space that was in a sense detached and separated from the time and space of both society (polis) and the household (oikos). The invention of the school constituted an emancipatory rupture and provided the 'format' for time-made-free, that is, the particular composition of time, space and matter that makes up the scholastic. With the coming into existence of the school form, we actually see the democratization

5 The Greek word scholè means, first of all, 'free time'. Other related meanings are: 'delay', 'rest', 'study', 'school', 'school building. 'Free time', however, is not so much leisure time, but rather the time of play, study and exercise, the time separated from the time of production. Scholé as time to cultivate one self and others, to take care of the self, i.e. of one's relation to self, others and the world. See Masschelein and Simons, 2010. 
of free time, which at once is, as Jacques Rancière argues, the 'site of the symbolic visibility of equality' (1995, p. 55). The school form should be regarded as the visible and material refusal of natural destiny.

Education, then, is different from initiation and socialization, in that it explicitly offers the new generations the possibility for renewal and the opportunity of making their own future i.e. a future that is not imposed or defined (destined, discerned or discovered) by the older ones. It is a way to deal with the new generation and the common world, which implies the acceptance of being slowed down (in order to enable the new generations to find, or even, make a destiny) and the decision to bring into play or put on the table the common world. We can also phrase it differently: taking up Arendt's suggestion that culture refers to "the mode of intercourse of man with the things of the world" (1960/2006, p. 210), and more specifically to "[taking] care of the things of the [common] world" (p. 211, our italics). We can maintain that the 'school' as a pedagogic form is amongst the most important ways in which this intercourse and "loving care" (p. 208) takes place in relation to the new generations. This is the case since they deal in a particular way with this new generations which constitute always at once a 'threat' to the common world (which "needs protection to keep it from being overrun and destroyed by the onslaught of the new that bursts upon it with each new generation", Arendt 1958/2006, p. 182), and a promise of its continuance and renewal ("our hope always hangs on the new which every generation brings", p. 189). Schools deal in a particular way with the new generations. Namely, they do not want the old generations to control or dictate how the new might or will look (i.e. they re-present the world by putting something on the table, but in that act, also setting it free and pre-senting it) and they form the new to be fit to take care of the common world and become 'in shape'. Schools do this precisely to the extent that they offer 'free time' or 'leisure time' (scholè), which is not simply vacant time ("left-over time"), but time to be devoted to study and exercise. As Tim Ingold writes: "Just as with the middle voice, in the lexicon of ancient Greece schole signified the flight of undergoing from the determination of doing". It is about un-finishing, undoing the appropriation and destination of time, catalyst of beginnings.

On this plane of immanence, where nothing is any more what it was or yet what it will be, there is-as the saying goes - everything to play for. Unfinished, freed up from ends and objectives, common to all, the world is once more restored to presence. It touches us, so that we-together exposed to its touch-can live with it, in its company. (Ingold, 2015, p. 146)

When using the term school referred to a specific pedagogic form, I am actually hinting at the rich practices and technologies that allow, on the one hand, for someone to experience himself or herself as being able to take care and, at the same time and on the other hand, to be exposed to something outside (common world) (see also Masschelein, 2011). It is a very specific combination of taking distance and (allowing for) re-attachment. Consequently, the term 'school' is not used-as is very often the case-to refer to the so-called normalizing institutions or machineries of reproduction in the hands of the cultural or economic elites. There is reproduction and normalizing, of course, but then the school does not (or no longer) function as a pedagogic form. There is an important element of slowness in this pedagogic form, exactly because immediate political, social or economic requests and claims are for a moment put at a distance or suspended (hence, not ignored or destroyed). Or more precisely, when being engaged with the world, and hence, when taking care of things, there is no point in meeting up with economic, social, cultural and political requirements and expectations that accelerate because from these outside perspectives and within their rationale there is no time to be lost-especially not at school.

If we follow this line of understanding we could say that pedagogical thought appears with the emergence of the school and that it is in Foucault's words part of the 'history of thought' as "the history of the way people begin to take care of something, of the way they become anxious about this or that", in this case about the way we deal with the arrival of newcomers, which, so long as they were considered as initiation or socialization could appear as "unproblematic field of experience, or set of practices, which were accepted without question, which were familiar and 'silent' out of discussion" but now "becomes a problem, raises discussion and debate, incites new reactions, and induces a crisis in the previously silent behavior, habits, practices and institutions" (Foucault, 2001, p. 134).

Focusing on the existence of schools as particular pedagogic forms along these lines, means at once to be ready to put oneself as society at a distance from oneself. Actually, in order to allow the coming generation to be a new one, a society that accepts schools must give and make (free) time, prevent that the claims from society overrule the claims laid on society by the new generation, put something on the 
table and set things of the world free, and, therefore, allow that these things slow down. This also means that such a society is forced to engage in a discussion about what kinds of 'grammars' they want to offer to the new generation in order to be able to take their future into their own hands. It means also to accept that what is at stake in education is not "men" or "women" as such (neither their life or their self-identity), but the common world and the ability "to take care of the things of the world" (Arendt $1960 / 2011$, p. 211). That is, to become 'in shape' in relation to some-thing, to establish an ability to judge and take one's life into one's hands, an ability to do justice to the world.

Education, thus, is not in the first place about needs and functions, not even about values. As Arendt states, 'values', even 'cultural values', are "what values always have been, exchange values, and in passing from hand to hand they [are] worn down like old coins" (1960/2011, p. 201). Education is a set of practices to keep the things of the world out of the circles of consumption and the business of use and exchange value. It is about "common things" that have "the faculty of arresting our attention and moving us" (p. 201). In this sense, we can consider 'schools' to belong to the most elementary part of the heritage that allows taking care of the common world. Precisely because Arendt also states that this heritage is today offered to us without testament (Arendt, 1961/2006, p. 3), it seems that it is in need of our explicit support in the moment that schools are reconceived as learning environments where the common world is transformed into a pool of available resources for fast learning and producing predefined outcomes. This predefinition being required in order to design the production process as efficient and effective as possible, implying that there is no difference anymore between school time and 'social' time: both being time of production. As Maarten Simons and myself argued also elsewhere, it is time to defend and reclaim the school as a pedagogic form (not as an institution) (Masschelein \& Simons 2013, 2015).

To reclaim the school means, first of all, to take it from the hands of those who do not allow the coming generation to be a new generation. It is not only the hands of the political and cultural conservatives, but also the hands that in the name of progress turn schools into learning environments and, whether implicitly or explicitly, favor fast learning. To reclaim the school is not about restoring classic or old techniques and practices, but actually trying to develop or experiment with old and new techniques and practices in view of designing a pedagogic form that works. That is, one that makes 'free time' and actually slows down, and puts society at a distance from itself. In these attempts, I want to reemphasize that the school as pedagogic form includes a very particular idea of equality. As I mentioned above, in line with Rancière (1991), one could argue that pedagogic action starts from the assumption of equality, that is, the assumption that everyone should be able to (know, understand, speak, and so on). Equality in pedagogic terms is not a fact, but a kind of assumption that is verified in pedagogic action. This equality is closely related to the assumption that human beings have no natural (or culturally, socially imposed) destiny, and hence, they can and have to find and shape their own destiny. This assumption is not making education impossible. On the contrary, there being no (natural) destiny, it makes education possible - in terms of bringing oneself into shape-, and provides it with meaning. It is important to stress that a pedagogic perspective is different from - and not to be reduced to- a political, ethical or cultural perspective. I cannot elaborate this in detail here, but one could think of the pedagogic perspective as referring to the assumption of equality and freedom in terms of 'being able to...', while the ethical perspective often includes a point of departure in terms of 'having to' or 'being unable not to'. Furthermore, both politics and pedagogics are concerned with change, but collective change through reform is different from renewal initiated by a new generation. Yet, it is clear that politics often uses schools for reform, and hence exploits the coming generation as a resource to solve problems in current society. Perhaps, the school should not be politicized, but we should acknowledge that allowing schools to exist - as sites of pedagogic renewal- is a political act in itself. Finally, schools should not be mistaken as forms of initiation into a culture, or into norms and values of a society. In a sense, culture at the school is always already put at a distance, that is, it becomes a common thing that allows for study, exercise and thus renewal. However, spokespersons of 'the culture' often claim the school as a site of initiation. In our view, this does not do justice to schools, but reduces cultural work to schoolwork. This is not to say that schools are not cultural, or have nothing to do with culture. As far as the world and thing in common is put central stage, it actually 'makes' culture and prepares the new generation for culture. 


\section{Conclusion-Pedagogical sciences as design sciences?}

Let me conclude these notes by suggesting that, given the current conditions, it is not only worthwhile to defend and reclaim the school, but that precisely it is important to emphasize the need for pedagogical sciences. I cannot develop this in detail. I should in fact clarify how 'pedagogical' here does not only refer to the issue these sciences are dealing with, but it also affects the way we understand 'sciences'. However, I will limit myself here to the suggestion that pedagogical sciences should focus on the support and reinvention or re-design of the pedagogic form of the school. Therefore, such sciences are not interested in formulating benchmarks but in the articulation of touchstones, i.e. no measures of performance but measures of authenticity in order to investigate whether and how new forms of gathering people and things, new designs can be considered as being truly a school. Our defense of the school intended to contribute to the formulation of such a touchstone (Masschelein \& Simons, 2013), but it is also important to briefly indicate why this is related to the art of design.

It is common for learning sciences to call themselves design sciences, and I want to suggest that pedagogical sciences should also be design sciences. However, there are many differences with learning sciences. These are interested in the design of environments that support and enhance learning, as understood in terms of producing predefined learning outcomes and of being responsive to diverse learners, learner needs and contexts. Their main concern being to create productive environments and increase effectiveness and efficiency, which implies that outcomes have to be predefined, otherwise it makes no sense to investigate effectiveness and efficiency. In other words, they are mainly concerned with mechanisms and functions, but these always require a stable world. No function can deal with learning new habits or initiating new or diverging worlds, worlds and habits that challenge any predefinition.

Pedagogical sciences are not interested in the design of learning environments, but of schools i.e. in the design of a particular 'unoccupied time'. They are not interested in functions and mechanisms, but precisely in the operations and events that enable to suspend functions and mechanisms, and in the exercises, the architectures, the artifacts that sustain these operations and could invoke events. They are interested in practices of taking care and paying attention, rather than in practices of fabrication and production. Therefore, it is also particularly interesting to point to the way in which Vilhelm Flusser and Bruno Latour characterize design.

According to Flusser, what is so interesting about the word design is that it is

an expression of the internal connection between art and technology [...] design more or less indicates the site where art and technology (along with their respective evaluative and scientific ways of thinking) come together as equals, making a new form of culture possible (1999, p. 19)

Very importantly also in our context is that Flusser emphasizes the "awareness that being a human being is a design against nature" (p. 20). As he further explains, this notion of design allows reformulating the issue of matter and form. "Forms are neither discoveries nor inventions, neither Platonic Ideas nor fictions, but containers cobbled together for phenomena ('models')" (p. 26). That is, forms -in our case 'pedagogic' forms - are gatherings or associations of people and things. In a comment on the work by Peter Sloterdijk, Bruno Latour writes that the notion of design indicates "a change in the ways we deal with objects and action more generally" (2011, p. 152). In fact, he states that saying that something should be designed does not mean that it has to be revolutionized or modernized, or that it has to be constructed or build, or made or fabricated, but it means that an 'object' is turned into a thing, into a matter of concern. Designing is "drawing things together". For Latour, there are five advantages related to the use of the notion of design: (1) it suggests a non-promothean sense of what it means to act and implies modesty; (2) it is related to art, craft and skill and therefore always to artificiality -implying obsessive attention to detail, taking care and being meticulous and precise-, actually slowing down; (3) it is always a way of 'writing' and therefore to be situated in the field of meaning and signs (de-sign) - things being "complex assemblies of contradictory issues" ( $p$. 154); (4) design is always to re-design and never begins from scratch-it is not founding, establishing, breaking (with the past) or 'creating ex nihilo'; (5) in a particular way, it immediately has an ethical dimension since you cannot avoid the question whether something is good or badly designed.

To summarize, let us insist on the need for pedagogical sciences (and pedagogues) since they are directly related to the mode of existence of a society in which it relates in a particular way to its future and the future of the new generations. Let us insist on the concept of pedagogy as referring, in the first place, to the operations of 'school' and to practices of 
taking care and paying attention. Finally, let us insist on the quest for re-designing pedagogy in the face of contemporary challenges.

\section{References}

Adler, M. J. (1982). The Paideia Proposal. An Educational Manifesto. New York: Touchstone.

Arendt, H. (1958/2006). The crisis in education. In: Between Past and Future (pp. 170-193). New York: Penguin.

Arendt, H. (1960/2006). The crisis in culture: Its social and its political significance. In: Between Past and Future (pp. 194-222). New York: Penguin.

Arendt, H. (1961/2006). Preface: The Gap Between Past and Future. In Between Past and Future (pp. 2-15). New York: Penguin.

Art Resource. Retrieved from: http://www.artres.com/C. aspx?VP3=ViewBox_VPage\&raqf=1\&IT=ZoomImageT emplate01_VForm\&iid=2untwaa $45 \mathrm{mn} 5 \&$ alid $=2$ untw a9jjwws\&pn=32\&ct=Search\&sf $=0$

Bernfeld, S. (1925/1973). Sisyphos oder die Grenzen der Erziehung. Frankfurt/M.: Suhrkamp.

Biesta, G. (2006). Beyond learning: Democratic education for a human future. Boulder: Paradigm Press.

Blacker, D. J. (2013). The falling rate of learning and the neoliberal endgame. Winchester/Washington: Zero-Books.

Blackmore, J.; Manninen, J.; Creswell, J.; Fisher, K. \& Ahlefeld H. von . (2013). Effectiveness, efficiency and sufficiency: An OECD framework for a physical learning environments module. Retrieved on 6/11/2014 from: http://www. oecd.org/edu/innovation-education/centreforeffectivelearningenvironmentscele/LEEPFrameworkforwEB. docx

Castle, E. B. (1961). Ancient education and today. Harmondsworth: Pelican.

Foucault, M. (2001). Fearless Speech. Edited by Joseph Pearson. Semiotext(e)

Flusser, V. (1999). The shape of things. A philosophy of design. London: Reaktion Books.

Gros, F. (2001). Situation du cours. In M. Foucault, L'herméneutique du sujet. Cours au Collège de France (1981-1982) (pp. 488-526). Paris: Gallimard.

Groys, B. (2015). En Public. Poétique de l'auto-design. Paris: PUF.
Hacking, I. (2002). Inaugural Lecture: Chair of Philosophy and History of Scientific Concepts at the Collège de France, 16 January 2001. Economy and Society, 31(1), 1-14.

Harten, T. (1999). Paidagogos. Der Pädagoge in der griechischen Kunst. Kiel.

Ingold, T. (2015). The Life of Lines. London/New York: Routledge.

International Society of the Learning Sciences. Welcome to ISLS. Retrieved on 26/08/2015 from: https://www. isls.org/.

Jaeger, W. (1947). Paideia; die Formung des griechischen Menschen, 3 vols. Berlin: De Gruyter.

Latour, B. (2011). A Cautious Prometheus? A Few Steps Toward a Philosophy of Design with Special Attention to Peter Sloterdijk. In L. Noordegraaf-Eelens, \& W. Schinkel (eds.) (2011). In Medias Res. Peter Sloterdijks' Spherological Poetics of Being (pp. 151-164). Amsterdam: Amsterdam University Press.

Lewis, T. (2013). On study: Giorgio Agamben and Educational potentiality. New York: Routledge.

Masschelein, J. (2011). Experimentum Scholae: The world once more... But not (yet) finished. Studies in Philosophy and Education, 30 (5), 529-535.

Masschelein, J. \& Simons, M. (2013). In defense of the school. A public issue. Leuven: E-ducation, Culture \& Society Publishers. Available at https://ppw.kuleuven.be/ecs/ les/in-defence-of-the-school/masschelein-maartensimons-in-defence-of-the.html

Masschelein, J. \& Simons, M. (2015). Lessons of/for Europe. Reclaiming the school and the university. In: Gielen P. (Eds.), No culture, no Europe. On the foundation of politics (pp. 143-164). Amsterdam: Valiz.

Miller, R. (2007). Towards a learning intensive society. Retrieved on 6/11/2014 from http://www.urenio. org/futurreg/files/making_futures_work/Towardsa-Learning-Intensive-Society_The-Role-of-FuturesLiteracy.pdf

Miller, R.; Shapiro, H. \& Hilding-Hamann, K. E. (2008). School's Over: Learning Spaces in Europe in 2020: An Imagining Exercise on the Future of Learning. Retrieved on 12/10/2015 from: http://ipts.jrc.ec.europa.eu/ publications/pub.cfm?id=1780

Peters, M. (2004). Geophilosophy, Education and the Pedagogy of the Concept. Educational Philosophy and Theory, 36 (3), 217-226. 
Rancière, J. (1991). The ignorant schoolmaster. Five lessons in intellectual emancipation. Stanford: Stanford University Press.

Ranciere, J. (1995). On the shores of politics. London: Verso.

Ricken, N. (1977). Subjektivität und Kontingenz: Markierungen im pädagogischen Diskurs. Würzburg: Königshausen \& Neumann.

Roberts, P. A. \& Steiner, D. J. (2010). Critical public pedagogy and the Paidagogos. Exploring the normative and political challenges of radical democracy. In: J. A. Sandlin, B. D. Schultz \& J. Burdick (eds.). Handbook of Public Pedagogy. Education and Learning Beyond Schooling (pp. 20-27). New York/London: Routledge.

Schulze, H. (1998). Ammen und Pädagogen. Sklavinnen und Sklaven als Erzieher in der Antiken Kunst und Gesellschaft. Mainz: Verlag Philipp von Zabern.

Serres, M. (1997). The troubadour of knowledge. (S. F. Glaser \& W. Paulson, trans.). Ann Arbor: The University of Michigan Press.
Simons, M. \& Masschelein, J. (2007). De-governmentalisation of education and the meaning of the public. Paper presented at the 2007 meeting of the American Educational Research Association. Chicago, USA.

Simons, M. \& Masschelein, J. (2008a). The governmentalization of learning and the assemblage of a learning apparatus. Educational Theory, 58 (4), 391-415.

Simons, M. \& Masschelein, J. (2008b). From schools to learning environments: The dark side of being exceptional. Journal of Philosophy of Education, 42 (3-4), 687-704.

Stengers, I. (2005a). Deleuze and Guattari's last enigmatic message. Angelaki, 10 (2), 151-167.

Stengers, I. (2005b). An ecology of practices. Cultural Studies Review, 11 (1), 183-196.

Stiegler, B. (2006/2008). La télécratie contre la démocratie. Paris: Flammarion.

Wikipedia. https://en.wikipedia.org/wiki/Learning_sciences Retrieved on 26/08/2015

Wisegeek, What is pedagogical science? Retrieved on 27.08.2015 from: http://www.wisegeek.com/whatis-pedagogical-science.htm 